\title{
Pedagogical portfolio in 3D MaxWhere virtual space
}

\author{
Viktória Kövecses-Gősi - Ildikó Lőrincz - Bálint Lampert
}

\begin{abstract}
Compiling a portfolio based on teacher's self-assessment within the frames of teacher's career cycle model has been introduced in Hungary recently so that teachers could demonstrate their career, achievements, and competences. Parallel to these efforts one of our important tasks was to elaborate a system, within the frames of teacher training, which prepares our students for the career cycle model and the related tasks. The present paper introduces a programme which aims to develop the digital competences of future teachers by applying $3 \mathrm{D}$ virtual spaces during the compilation of student portfolio at Apáczai Csere János Faculty of Széchenyi István University. Keywords: portfolio; teacher's career cycle model; Moodle; MaxWhere 3D VR; pedagogical competences

Subject-Affiliation in New CEEOL: Social Sciences - Education - Higher Education DOI: $10.36007 /$ eruedu.2020.4.005-020
\end{abstract}

\section{Introduction}

"There are probably a few professions on which society makes so controversial claims like those of teachers: to lead the errant group of top athletes and people with disabilities in fog, pathless roads, and north-south direction in a way that everybody could arrive to the three different targets preferably at the same time and in the best mood possible."

(Hans Vollener)

The classification of teacher's career cycle model and a set of requirements that are needed to complete the stages of the classification are defined by the \$64-65 of Act CXC of 2011 on National Public Education and the 326/2013. (VIII.30.) Government Decree on the Promotion System for Teachers and the Implementation of Act XXXIII of 1992 on the Status of Public Servants in Public Education Institutions.

An element of this is the portfolio to be compiled by teachers, which is aimed to demonstrate the teacher's professional knowledge at first along eight, but since the summer of 2019, nine areas of competence. The nine areas of competence include:

- professional tasks, knowledge of specific science, vocational subjects and curriculum;

- the planning of pedagogical processes, activities and the related self-reflections; 
- support for learning;

- the development of the student's personality, the fulfilment of individual treatment, the appropriate methodological preparedness necessary for the successful and integrated education and training of disadvantaged children or children with special needs or with difficulties in their integration, learning, behaviour;

- the facilitation and development of the formation of student groups and communities, creating opportunities, openness to social-cultural diversity, integration activity, homeroom teacher's activity;

- the continuous evaluation and analysis of pedagogical processes and students' personality development;

- the method of teaching environmental education skills, the credible representation of the values of sustainability and the attitudes towards environmental awareness;

- communication, professional cooperation, and problem-solving;

- the commitment to and professional responsibility for professional development. (Government Decree on the Promotion System for Teachers and the Implementation of Act XXXIII of 1992 on the Status of Public Servants in Public Education Institutions)

According to the $\S 8(1)$ of the 326/2013. (VIII.30.) Government Decree on the Promotion System for Teachers and the Implementation of Act XXXIII of 1992 on the Status of Public Servants in Public Education Institutions, the portfolio, demonstrating the professional knowledge of teachers, means the following: "portfolio is a collection of documents based on which the development of pedagogical competences, the teacher's professional career, activities, difficulties and successes can be seen in view of the facts as well as based on the teacher's reflections and interpretation." (Government Decree on the Promotion System for Teachers and the Implementation of Act XXXIII of 1992 on the Status of Public Servants in Public Education Institutions)

Pedagogical literature includes several definitions of portfolio. Portfolio "is a collection of documents which shed light on someone's knowledge, skills, and attitude in a given field." (Kimmel-Falus 2008, 196-214) "A purposeful collection of student's work, which presents the student's efforts, progress, and achievements in one or more fields. Student must take part in the compilation of the content, the collection must include the criteria for sorting documents and the student's self-reflections." (Kimmel-Falus 2008, 196-214)

There are basically two reasons for creating a portfolio. It can serve for evaluation and facilitating learning. The whole learning process can be documented with the help of the portfolio. It enables continuous evaluation, feedback, and self-assessment. It facilitates the development of reflective thinking, getting to know and understanding our metacognitive knowledge, which is the knowledge of our own thinking and learning process. Using the portfolio enables its composer to be an active participant in their own learning process and it is also typical that digital devices are embedded in the evaluation process in more and more areas. (Lénárd-Rapos 2006) Recently it has become a more emphasised requirement towards student 
evaluation to really facilitate the student's personality development. This has led to the emergence of new definitions destined for expressing a changed approach of the function, form and means of evaluation. The concept of authentic evaluation has emerged as a contrast to traditional knowledge testing. This definition refers to the efforts made to get to know the student's authentic, real personality, which manifests itself in solving real problems and is based on the student's own creations and the results of the learning process. (E. Gogh, A. Kovari 2019, 72-86) A form of authentic evaluation, which may even go beyond that, is portfolio. (Albert 2009, 84)

In addition to documents proving competence areas it is highly important to provide these documents with reflections. The emergence of reflective pedagogical thinking can be linked to the emergence of reform pedagogies. John Dewey sees reflection (perception) as a form of thinking which derives from the uncertainty of a specific experience, situation and leads to problem-solving. "Schön describes reflection as an experiment in which the role of reflection is no other than to enable dialogue between the reflective and the problem-generating situation." $\mathrm{He}$ believes that ,layman differs from the expert in the way he uses his theoretical and practical knowledge, frames the problem with the help of cognitive schemes and structures." (Szivák 2003, 9)

Reflective thinking and practice is based on previous experiences, the teacher's values and presuppositions and on the system of special professional abilities. Reflection appears in several cases during pedagogical activities. When analysing or discussing a problematic situation or an applied pedagogic method, teachers, by developing new solution techniques, may reflect to their own and other's pedagogical work as well as to the activities and behaviours of students and parents. Sinnika Ojanen, a Finnish researcher thinks that ,those teachers are more effective who deliberately reflect as they know what they do and what its consequences will be. In absence of this latter the individual becomes a slave to chance and superstition." (Szivák 2003, 12) According to Ojanen, reflection is a link between theory and practice.

According to Taggart and Wilson (1998), three levels of reflection can be distinguished: (Szivák 2010, 18)

Technical level: reflection refers to the "means" of education, it mainly analyses the selection and optimality of contents, supplementary materials. "What do I teach tomorrow? Which exercise do we deal with in the class?"

Contextual level: reflection focuses on the comparison and the clarification of theory and practical experiences, and forms the teacher's own practical knowledge. "How could I hold the students' spellbound better?"

Dialectical level: reflection points beyond the actual problems and situations of teaching practice, and puts them in a wider social and ethical context. "What does equal opportunity mean to me? Is it right to fail?"

It is necessary to provide reflections to the compulsory and free optional documents of teacher training student's portfolio. 


\section{The past and the current situation}

Portfolio as a developmental evaluation form had been continuously implemented in case of some subjects of teacher training in Györ until the academic year of 2013/2014 (e.g. Department of Pedagogy: Applied pedagogy: project portfolios, Group pedagogical practice, Environmental education, Differentiating pedagogy, Sustainable development, Cooperative learning, Visual specialisation: masterpiece portfolio, Foreign language specialisation: language portfolios).

We assigned great importance to the implementation of developmental evaluation and reflective pedagogical practice in our education activities. "Developmental evaluation means the frequent and interactive assessment of the student's development and knowledge, and its aim is to define learning objectives and to harmonise them with teaching." (Rapos, Lénárd 2009, 20) It is important for students to gain experience during their own evaluation processes, which they can later use in their teaching practice.

Having seen the guidelines and directives published in public education, we elaborated the preparation for teacher's career cycle model for our students within the frames of more subjects in the 2 nd semester of the academic year of 2013/2014: Group pedagogical practice for both full-time and part-time students of 3rd grade, Topical issues of pedagogy subject after the eight weeks of teaching practice for students of 4th grade and the free optional course, Pedagogical portfolio for part-time students of the same grade. Reflectivity in pedagogy, a free optional course, facilitated the more effective implementation of the processes for both full-time and part-time students. Besides these, it has become necessary to prepare the teacher trainees in a coordinated and continuous way for portfolio-related tasks from the beginning of the training.

\section{The objectives and tasks of the project}

After graduation our teacher trainees begin their career as apprentices, therefore it was necessary to implement a programme which enables us to prepare them, during the four years, for career cycle model by considering the set of requirements for apprentices. Obviously the qualification requirements of teacher training cover these areas, however, it was essential to systematise them, to develop a portfolio approach, and to disseminate reflective pedagogical practice more widely. In cooperation with the departments involved in teacher training we aimed at introducing the essential elements of portfolio and teacher's promotion system required by the government decree into teacher training.

Another aim was to have the teacher training students know the content of the government decree in general and the elements of the teacher's career cycle model by concentrating mainly on the first stage, the period of apprenticeship.

We considered it important that the new pedagogical culture (portfolio approach, developmental evaluation, and the practice of reflective thinking) should become more widespread within the faculty during the innovation process. 
Moreover, another aim was to prepare, based on professional materials, the assessment sheets and guide materials needed for compiling the portfolio, to create the IT background, to acquaint the lecturers with the Moodle system, and to help the preparation for work processes.

In cooperation with the departments involved in teacher training it was our task to define the contents of the portfolio in relation to different areas of competence, to elaborate the evaluation system related to the tasks of portfolio, to think through the forms of portfolio management, and to create the IT background with the help of Moodle system. Having elaborated all these, we asked for the approval of the Faculty Council.

Following our initial discussions, the various departments made suggestions on what compulsory and free optional documents the students could choose for their pedagogical portfolio in the given semester considering the areas of competence, the subject tasks, and the qualification requirements. Table 1 illustrates a non-exhaustive collection which is highlighted from the subjects of the department.

Table 1:

Document types suggested by the Department of Pedagogy related to its subjects (Kövecsesné 2015, 264-273.)

\begin{tabular}{|l|l|}
\hline Pedagogical competences & Document types \\
\hline $\begin{array}{l}\text { K1 Professional tasks, } \\
\text { knowledge of specific sci- } \\
\text { ence, vocational subjects } \\
\text { and curriculum }\end{array}$ & $\begin{array}{l}\text { Didactics, Theory of education: Evaluative analysis of } \\
\text { studies, Show plan for national holiday } \\
\text { Minutes of class observations... }\end{array}$ \\
\hline $\begin{array}{l}\text { K2 The planning of } \\
\text { pedagogical processes, } \\
\text { activities and the related } \\
\text { self-reflections }\end{array}$ & $\begin{array}{l}\text { Environmental education, Education for sustainabili- } \\
\text { ty: plan for thematic day, thematic week ... } \\
\text { Individual complex practices: Minutes of school obser- } \\
\text { vations ... }\end{array}$ \\
\hline $\begin{array}{l}\text { K3 Support for learning } \\
\text { Applied pedagogy: Management plan for intraday } \\
\text { home learning, Outline of study methodology lesson, } \\
\text { Assessment of one student's learning habits and style, } \\
\text { recommendations for study methodology, formulating } \\
\text { ideas ... }\end{array}$ \\
\hline $\begin{array}{l}\text { K4 The development of } \\
\text { the student's personality }\end{array}$ & $\begin{array}{l}\text { Differentiating pedagogy: Differentiation with coope- } \\
\text { rative techniques, Appearance of differentiation aimed } \\
\text { at developing different intelligence areas in the lesson } \\
\text { plan, "Developmental game library" }\end{array}$ \\
\hline $\begin{array}{l}\text { K5 The facilitation and } \\
\text { development of the forma- } \\
\text { tion of student groups and } \\
\text { communities }\end{array}$ & $\begin{array}{l}\text { Applied pedagogy: Plan for homeroom lesson, } \\
\text { camping practice, Planning leisure play activities in the } \\
\text { day care centre } \\
\text { Making sociometry in a class } \\
\text { Creating game library for community development } \\
\ldots\end{array}$ \\
\hline
\end{tabular}




\begin{tabular}{|l|l|}
\hline $\begin{array}{l}\text { K6 The continuous } \\
\text { evaluation and analysis of } \\
\text { pedagogical processes } \\
\begin{array}{l}\text { and students' personality } \\
\text { development }\end{array}\end{array}$ & $\begin{array}{l}\text { Developmental psychology: Differentiating psycho- } \\
\text { logy: } \\
\text { Analysis of drawings of the family, anamnesis, analysis } \\
\text { of drawings of humans } \\
\text { Pedagogical psychology: Testing and analysis of effec- } \\
\text { tive student cognitive techniques } \\
\text { Differentiating pedagogy: Introducing a student's in- } \\
\text { dividual development opportunities as observed during } \\
\text { school practice... }\end{array}$ \\
\hline $\begin{array}{l}\text { K7 The method of } \\
\text { teaching environmental } \\
\text { education skills, the } \\
\text { credible representation of } \\
\text { the values of sustainability } \\
\text { and the attitudes towards } \\
\text { environmental awareness }\end{array}$ & $\begin{array}{l}\text { Forest pedagogy: Preparation of student projects } \\
\text { Applied pedagogy: Planning and implementing the } \\
\text { stages of Researchers' Night interactive exhibition in } \\
\text { group work }\end{array}$ \\
\hline $\begin{array}{l}\text { K8 Communication, pro- } \\
\text { fessional cooperation, and } \\
\text { problem-solving }\end{array}$ & $\begin{array}{l}\text { Theory and practice of organising forest school lear- } \\
\text { ning: Elaboration of a forest school programme } \\
\text { ference of Scientific Students' Associations, forest } \\
\text { school....... }\end{array}$ \\
\hline $\begin{array}{l}\text { K9 The commitment to } \\
\text { and professional res- } \\
\text { ponsibility for professional } \\
\text { development }\end{array}$ & $\begin{array}{l}\text { Reflectivity in pedagogy: observation and self-obser- } \\
\text { vation of pedagogical skills, analysis of video recordings } \\
\text { Group pedagogical practice: Self-reflective essay on } \\
\text { own career }\end{array}$ \\
\hline
\end{tabular}

Following the brainstorming of the departments, and after a joint discussion, Table 2 was compiled which we modified in accordance with our new curriculum of 2017 , and currently this is relevant for our teacher training students. Thanks to the work of the departments, a more practice-oriented task determination that integrates theory into practice more effectively has become typical in the training. The documents included in the portfolio, of course, could be selected by the students out of the tasks of the semester subjects. Besides obligatory, obligatory elective and free optional subject blocs, everyone had the chance to highlight, from their own practice, those moments which they considered important from the viewpoint of career cycle model.

A guide for creating portfolio was made and it has also been included in the Education and Exam Regulations. Based on the decision of the Faculty Council it is compulsory for students to create a pedagogical portfolio which is a prerequisite for applying for the final exam. Following the processes, the preparation of the $1 \mathrm{st}$ grade students, the creation of the four-year portfolio began in the 1st semester of the academic year of 2014/2015. Portfolio defence takes place in the course of contact hours in the last semester, after the eight-week long practice. 
Table 2:

Excerption of the documents of pedagogical portfolio required for teacher training students (Kövecsesné 2015, 264-273.)

\begin{tabular}{|c|c|}
\hline \multicolumn{2}{|c|}{$\begin{array}{l}\text { Recommended documents of pedagogical portfolio required for a teacher training } \\
\text { student in the course of the eight semesters } \\
\text { Syllabus for the academic year of } 2017 / 2018\end{array}$} \\
\hline Semesters, subjects & Subject tasks, uploadable documents \\
\hline $\begin{array}{l}\text { 1st semester: } \\
\text { Introduction to psychology } \\
\text { and Pedagogical portfolio }\end{array}$ & $\begin{array}{l}\text { „For the first time in school as a trainee teacher" } \\
\text { (Self-reflective essay) }\end{array}$ \\
\hline Pedagogical informatics & $\begin{array}{l}\text { Getting to know the use of electronic interface } \\
\text { (e-Portfolio), Making a presentation based on a } \\
\text { set of given aspects, useful mobile applications in } \\
\text { education }\end{array}$ \\
\hline Mathematics and education I. & $\begin{array}{l}\text { Making a poster (both in paper-based and digital } \\
\text { form) selected from the topics of the subject }\end{array}$ \\
\hline $\begin{array}{l}\text { Language development (Fo- } \\
\text { reign language specialisation) }\end{array}$ & Making a magazine/journal in a foreign language \\
\hline $\begin{array}{l}\text { 2nd semester: } \\
\text { Theory and practice of } \\
\text { teaching and learning in early } \\
\text { childhood education }\end{array}$ & $\begin{array}{l}\text { A collection of cooperative techniques (15-20 } \\
\text { techniques)/or a collection of study methodology } \\
\text { practices } \\
\text { Minutes of class observation (observation of tea- } \\
\text { ching methods and organization methods) }\end{array}$ \\
\hline Psychology of 6-12 year olds & $\begin{array}{l}\text { Presentation of an area of development of a chosen } \\
\text { age period as a result of an independent investiga- } \\
\text { tion } \\
\text { Getting to know the optional area of student perso- } \\
\text { nality as a result of an independent investigation }\end{array}$ \\
\hline $\begin{array}{l}\text { Individual complex practice II. } \\
\text { ( } 2 \text { days) }\end{array}$ & $\begin{array}{l}\text { Minutes of individual complex practice II. (kindergar- } \\
\text { ten school observation) }\end{array}$ \\
\hline $\begin{array}{l}\text { Mathematics and education } \\
\text { II. }\end{array}$ & $\begin{array}{l}\text { Net of } 5 \text { regular bodies with hand drawing compiled } \\
\text { with photo }\end{array}$ \\
\hline $\begin{array}{l}\text { Methodological bases of } \\
\text { school experimentation ( } \mathrm{Na}- \\
\text { tural science specialisation) }\end{array}$ & $\begin{array}{l}\text { Preparing an occupational plan for a demonstrative } \\
\text { experiment of natural science }\end{array}$ \\
\hline $\begin{array}{l}\text { History I. (People and society } \\
\text { specialisation) }\end{array}$ & $\begin{array}{l}\text { Compilation and presentation of a specific section } \\
\text { of the } 5 \text { th grade History curriculum based on the } \\
\text { textbook and own research }\end{array}$ \\
\hline Prevention & $\begin{array}{l}\text { National Fitness Test, Preparing an individual devel- } \\
\text { opment plan for a pupil chosen by the student }\end{array}$ \\
\hline
\end{tabular}




\begin{tabular}{|l|l|}
\hline 3rd semester: & $\begin{array}{l}\text { Testing and analysing effective student cognitive } \\
\text { techniques }\end{array}$ \\
$\begin{array}{l}\text { Individual complex practice } \\
\text { III. (1 week when starting } \\
\text { school) }\end{array}$ & $\begin{array}{l}\text { Introducing the problems of transition between kin- } \\
\text { dergarten and school: minutes of observations and } \\
\text { school observations. }\end{array}$ \\
$\begin{array}{l}\text { Native language subject } \\
\text { pedagogy II. }\end{array}$ & $\begin{array}{l}\text { Creating an exercise bank based on the textbooks } \\
\text { selected for word processing. Related to literature } \\
\text { and historical readings. The workbook should inclu- } \\
\text { de } 10 \text { exercises per each text type. }\end{array}$ \\
$\begin{array}{l}\text { History II. (People and soci- } \\
\text { ety specialisation) }\end{array}$ & $\begin{array}{l}\text { Compilation and presentation of a specific section } \\
\text { of the 6th grade History curriculum based on the } \\
\text { textbook and own research }\end{array}$ \\
$\begin{array}{l}\text { Environmental and sustaina- } \\
\text { bility education (compulsory } \\
\text { elective subject) }\end{array}$ & $\begin{array}{l}\text { Making an environmental educational board game, } \\
\text { thematic day, plan for project week }\end{array}$ \\
\hline
\end{tabular}




\begin{tabular}{|c|c|}
\hline 4th semester: & \\
\hline Theory of education & E.g. Show plan (e.g. 15 March or Mother's Day....) \\
\hline $\begin{array}{l}\text { Individual complex practice } \\
\text { IV. (1 day) }\end{array}$ & $\begin{array}{l}\text { Observation and analysis of educational tasks based } \\
\text { on given aspects }\end{array}$ \\
\hline Social psychology & $\begin{array}{l}\text { Observation of group dynamic processes, making } \\
\text { sociometry }\end{array}$ \\
\hline $\begin{array}{l}\text { Native language subject } \\
\text { pedagogy III. }\end{array}$ & $\begin{array}{l}\text { Making a lesson plan that processes new knowledge } \\
\text { in the subject of Hungarian language (we recom- } \\
\text { mend it from the topic of word classes in 3rd grade), } \\
\text { and a collection of text creation strategies and } \\
\text { methods for composition lesson. Making a workbook } \\
\text { consisting of } 20 \text { exercises for spelling skills develop- } \\
\text { ment (with minimum } 5 \text { types of exercises). }\end{array}$ \\
\hline $\begin{array}{l}\text { Environmental studies sub- } \\
\text { ject pedagogy }\end{array}$ & $\begin{array}{l}\text { Group work (exhibition, experimental demonstration, } \\
\text { poster, etc. with brochure and documented on a } \\
\text { photo or film), lesson plan/thematic plan for environ- } \\
\text { mental studies of } 1 \text { st- } 4 \text { th grades }\end{array}$ \\
\hline $\begin{array}{l}\text { Mathematics III. } \\
\text { Visual education subject } \\
\text { pedagogy }\end{array}$ & $\begin{array}{l}\text { Net of } 5 \text { regular bodies with hand drawing compiled } \\
\text { with photo } \\
\text { Upload } 4 \text { lesson plans in accordance with the } 4 \\
\text { subject types with the illustrations of the expected } \\
\text { works of children, make a worksheet for } 3 \text { rd grade } \\
\text { students. }\end{array}$ \\
\hline $\begin{array}{l}\text { Foreign language speaking } \\
\text { and writing practice III. }\end{array}$ & $\begin{array}{l}\text { Essay/Abhandlung: "problem-solving", } 600-800 \\
\text { words } \\
\text { Suggested topics: how to become a language } \\
\text { teacher, a good language teacher, theoretical edu- } \\
\text { cation, financial problems in schools, urban/rural } \\
\text { schools, generational problems... }\end{array}$ \\
\hline $\begin{array}{l}\text { Methodology of organising } \\
\text { forest school learning (com- } \\
\text { pulsory elective subject) }\end{array}$ & Planning a 90 minutes long forest guidance. \\
\hline
\end{tabular}




\begin{tabular}{|c|c|}
\hline 5th semester: & \\
\hline Applied pedagogy & $\begin{array}{l}\text { Plan for homeroom lesson, camping practice diary } \\
\text { Management plan for intraday home learning }\end{array}$ \\
\hline Differentiating pedagogy & $\begin{array}{l}\text { Analysis of drawings of the family, anamnesis, analy- } \\
\text { sis of drawings of humans }\end{array}$ \\
\hline $\begin{array}{l}\text { Choir conducting (Music } \\
\text { specialisation) }\end{array}$ & $\begin{array}{l}\text { Conducting a song, a musical composition or even } \\
\text { organising a concert of works acquired during the } \\
\text { semester, concert organisation tasks, compilation of } \\
\text { works. }\end{array}$ \\
\hline $\begin{array}{l}\text { Foreign language speaking } \\
\text { and writing practice IV. }\end{array}$ & $\begin{array}{l}\text { Presentation/ Präsentation/: slides, synopsis- in } \\
\text { foreign language. } \\
\text { Suggested topics: based on personal interest about } \\
\text { the culture of the target language, personal experi- } \\
\text { ences in the world of school... }\end{array}$ \\
\hline Hungarian specialisation & $\begin{array}{l}\text { Hungarian language: we suggest to compile a met- } \\
\text { hodological exercise bank containing } 25 \text { exercises } \\
\text { including native language games, with at least } 5 \\
\text { types of exercises. In all cases, exercises must be in } \\
\text { accordance with the } 5 \text { th and 6th grade curriculum. } \\
\text { Hungarian literature: the student must make a system } \\
\text { of analysis criteria for literary work, and introduce the } \\
\text { strategies of the analysis of literary work by focusing } \\
\text { especially on attitudes, methods and the different } \\
\text { reading strategies }\end{array}$ \\
\hline $\begin{array}{l}\text { Methodology of teaching } \\
\text { history (People and society } \\
\text { specialisation) }\end{array}$ & $\begin{array}{l}\text { Making a plan for an interactive history lesson for } \\
\text { a part of } 5 \text { th-6th grade curriculum, concentrating } \\
\text { especially on historicity and visual experiences }\end{array}$ \\
\hline $\begin{array}{l}\text { Visual education specialisa- } \\
\text { tion }\end{array}$ & $\begin{array}{l}\text { In the 5th semester students who specialise in visual } \\
\text { education must upload their work diary related to } \\
\text { their masterwork exhibition (from the idea to the } \\
\text { final work with photo documentation), } 2 \text {. lesson plan } \\
\text { related to the given topic (it is a part of the program) } \\
\text { 3. the photo documentation of the masterwork as an } \\
\text { individual presentation }\end{array}$ \\
\hline
\end{tabular}




\begin{tabular}{|c|c|}
\hline 6th semester & \\
\hline $\begin{array}{l}\text { Theory and practice of integ- } \\
\text { rated, inclusive education }\end{array}$ & $\begin{array}{l}\text { Lesson plan with differentiated learning organisation } \\
\text { with self-assessment, introducing a student's indivi- } \\
\text { dual development opportunities as observed during } \\
\text { school practice }\end{array}$ \\
\hline Group teaching practice III. & Lesson plan with reflective self-assessment \\
\hline $\begin{array}{l}\text { Group teaching practice III. } \\
\text { specialisation }\end{array}$ & Lesson plan with reflective self-assessment \\
\hline $\begin{array}{l}\text { Conscious use of language II. } \\
\text { (specialisation) }\end{array}$ & $\begin{array}{l}\text { Project 1./project } 1 . \text { ( } 1500-2000 \text { words) } \\
\text { Possible project products: micro-teaching, exhibi- } \\
\text { tion, self-made storybook, journal, essay }\end{array}$ \\
\hline $\begin{array}{l}\text { Talent management in mathe- } \\
\text { matics (compulsory elective } \\
\text { subject) }\end{array}$ & $\begin{array}{l}\text { A worksheet with keys for a competition of 3rd-4th } \\
\text { grade students }\end{array}$ \\
\hline $\begin{array}{l}\text { School garden (compulsory } \\
\text { elective subject) }\end{array}$ & Garden-plan and lesson plan for gardening activity \\
\hline $\begin{array}{l}\text { Ethnography and local history } \\
\text { (People and society specia- } \\
\text { lisation) }\end{array}$ & $\begin{array}{l}\text { Introducing the ethnographic and local historical } \\
\text { values of the residence (objects, intellectual ethnog- } \\
\text { raphic artworks, the ethnic and religious composition } \\
\text { of the residence, family tree research) }\end{array}$ \\
\hline 7th semester & \\
\hline $\begin{array}{l}\text { Individual teaching practice } \\
\text { II. } 5 \text { days }\end{array}$ & $\begin{array}{l}\text { Lesson plans, self-assessment, evaluation by the } \\
\text { head of programme }\end{array}$ \\
\hline $\begin{array}{l}\text { German/English language } \\
\text { subject pedagogy III. }\end{array}$ & $\begin{array}{l}\text { Project 2./ project 2. (3000 words) } \\
\text { Topics: good practice: } \\
\text { - 'good practice'/experience gained at Erasmus } \\
\text { exchange programme or other study trip abroad, } \\
\text { getting to know a new school model, method } \\
\text { - Classroom research } \\
\text { - Case study about a student }\end{array}$ \\
\hline
\end{tabular}




\begin{tabular}{|c|c|}
\hline 8th semester & \\
\hline $\begin{array}{l}\text { Individual teaching practice } \\
\text { III. } 2 \text { months }\end{array}$ & $\begin{array}{l}\text { Evaluation by exercise instructor, minutes of pa- } \\
\text { rent-teacher meetings and consulting hours } \\
\text { Forms and opportunities of parent-teacher communi- } \\
\text { cations in practice } \\
\text { Self-reflective essay about own career, the pre- } \\
\text { sentation and evaluation of the portfolio in the last } \\
\text { semester }\end{array}$ \\
\hline Pedagogical portfolio II. & $\begin{array}{l}\text { Documents of final teaching (lesson plan, self-as- } \\
\text { sessment) }\end{array}$ \\
\hline School hygiene & Portfolio defence \\
\hline Natural science specialisation & Lesson plan for health education in 5th-6th grades \\
\hline
\end{tabular}




\begin{tabular}{|c|c|}
\hline $\begin{array}{l}\text { Free optional subjects: } \\
\text { Digital mathematics educa- } \\
\text { tion }\end{array}$ & Making and presenting an interactive curriculum \\
\hline $\begin{array}{l}\text { Demonstration in mathema- } \\
\text { tics education }\end{array}$ & $\begin{array}{l}\text { Preparation of illustrative material (digital or traditio- } \\
\text { nal) to assist mathematics education in lower school }\end{array}$ \\
\hline $\begin{array}{l}\text { Talent management in mat- } \\
\text { hematics }\end{array}$ & $\begin{array}{l}\text { A worksheet with keys for a competition of 3rd-4th } \\
\text { grade students }\end{array}$ \\
\hline Soul needs time & $\begin{array}{l}\text { Plan for EQ development lesson, creating a collecti- } \\
\text { on of } E Q \text { developing games } \\
\text { A collection of emotional intelligence developing } \\
\text { games }\end{array}$ \\
\hline $\begin{array}{l}\text { Child's game, child's dance } \\
\text { (specialisation) }\end{array}$ & $\begin{array}{l}\text { Presentation of a freely chosen region with folk dan- } \\
\text { ce and folk songs by means of PowerPoint presenta- } \\
\text { tion, compiling a set of games related to each other }\end{array}$ \\
\hline Other optional documents & $\begin{array}{l}\text { Conference participation } \\
\text { Participation in the Conference of Scientific Stu- } \\
\text { dents' Associations } \\
\text { Voluntary activities } \\
\text { Professional days } \\
\text { Retraining } \\
\text { Internships } \\
\text { Participation in projects (e.g. Researchers' Night, } \\
\text { language competitions) } \\
\text { Competitions for teachers } \\
\text { Events related to specialisations (e.g. visual: } \\
\text { exhibition, music: concerts, language: intercultural } \\
\text { meetings and projects, workshops on various topics } \\
\text { (methodological, competence developing, sensitising) } \\
\text { Erasmus experiences } \\
\text { New National Excellence Programme, scholarships } \\
\text { etc. }\end{array}$ \\
\hline
\end{tabular}

\section{Education in virtual spaces}

Ollé defines virtual environment as a three-dimensional (3D), artificial, and in reality a non-existent space where we and others can be present simultaneously in three-dimensional form and we see the same from our own viewpoints. (Ollé 2012, 9)

An important characteristic of these spaces is that they can be connected with computer-based, online, collaborative and technical means (Ollé 2012, 9) Furthermore, their typical elements are three-dimensional space, land surface, atmosphere, objects as well as simpler programs and algorithms that ensure the 
operation of all these. The position of each element (object, individual) can be accurately determined by a three-dimensional coordinate system. The perception of virtual space through the computer screen is very similar to looking into another real space using a movable camera, e.g. sightseeing with a web camera. (Ollé 2012, 10)

Thus, virtual reality is a simulated environment which tries to describe, simulate the processes of the real world by means of a computer model. It is a partially joint, shared space where more users can be present simultaneously. So the event, the activity takes place in real time and the online applications enable direct communication and cooperative work. Users may develop or create contents and compile documents. (Horváth 2017, 6-9)

A great advantage of VR environment is its availability independent of time and space, cost-effectiveness, and easy usability. By displaying information in an organised and parallel manner, the 3D VR learning environment facilitates the process of getting, filtering, receiving, elaborating and using information more effectively than traditional means of education. (Horváth 2017, 6-9)

\section{Pedagogical portfolio in 3D MaxWhere VR space}

The implementation of pedagogical portfolio took place through Moodle system at our faculty, however, recently, following the curriculum reforms and developments, we have thriven with a new background system. Curriculum development in MaxWhere 3D virtual spaces takes place within the frames of a university project at our faculty too. "Smart boards" appearing in different spaces provide a great opportunity for systematising information, displaying videos, pdf files, applications and websites, which simultaneously provide the opportunity for experiential learning in a transparent way in the given space. Project works and cooperative activities can also be perfectly fulfilled in the spaces.

More pieces of research have proven the effectiveness of MaxWhere 3D virtual spaces recently (Horváth 2017, 6-9), (Horváth 2019, 55-71). Based on these findings, the researchers of this field came to the conclusion that MaxWhere as an educational platform offered the users many opportunities to perform tasks that would otherwise require extremely complex digital workflows in more traditional 2D environment. Tests also proved that users could complete the necessary tasks at least 50\% faster in MaxWhere 3D environment than in case of any other content sharing platform. Experiments also showed that 3D environments are able to provide users with a much higher level of understanding in terms of sharing and interpreting digital workflows. (B. Lampert, A. Pongracz,, J. Sipos, A. Vehrer, \& I. Horvath 2018), (P. Baranyi., A. Csapo, G. Sallai 2015)

Starting with next semester teacher training students' portfolios will be systematised and presented with the help of this application. Currently students can use a document library related to the portfolio subject, which was elaborated by us and which can be found in SZE Öveges Kálmán space. This space includes all the knowledge and information needed for creating the final version of the portfolio 
as well as for its presentation. Graduate students get the curriculum in this form in the 2nd semester of the academic year of 2019/2020, and then they will present their own work in this form. The experience of this will be presented in the form of a study in the future.

\section{Summary}

During our activities we considered it important to give innovative responses to the changes in society and public education, and thus to increase the quality of our education.

A great importance of innovation is the fact that a real dialogue has begun between the different specialisations and departmental groups, which is a very important criteria of professional development.

By using MaxWhere 3D VR spaces we also aim to develop our students' digital competences as well as to provide them with alternatives related to the toolkit of digital pedagogy.

\section{References}

326/2013. (VIII.30.) Government Decree on the Promotion System for Teachers and the Implementation of Act XXXIII of 1992 on the Status of Public Servants in Public Education Institutions.

Kimmel Magdolna - Falus Iván (2008): The portfolio. In: Effective organization of teaching and learning, (Réthy Endréné) Educatio, Budapest. 196-214.

Lénárd Sándor - Rapos Nóra (2006): MAGtár - Ideas for teachers for developmental evaluation and adaptive learning organization. Budapest, OKI.

Albert Sándor (2009): Schools, values, vision. Comenius, Pécs.

Szivák Judit (2003): The development of reflective thinking, Education-methodological Library, Gondolat, Budapest.

Szivák Judit (2010): The development of reflective thinking, Géniusz Könyvek, Magyar Tehetségsegitö Szervezetek Szövetsége http://tehetseg.hu/sites/default/files/04_kotet_ net.pdf\#page=14 (15 January 2014).

Lénárd Sándor - Rapos Nóra (2009): Developmental Evaluation. Gondolat, Budapest.

Kövecsesné dr. Gösi Viktória (2015): Innovation in teacher training - The process of introducing the pedagogical portfolio in the teacher training of Györ. In: XVIII. Apáczai Napok Tudományos Konferencia. Tanulmánykötet. NyME AK Györ.

Ollé János (2012): Virtual environment, virtual education. ELTE, Bp. http://www.eltereader. hu/media/2013/11/OII\%C3\%A9_1_kotet_READER.pdf Downloaded: 15 January 2019.

Horváth Ildikó (2017): The latest means and methods of digital education. In: HTE MEDIANET Volume LXXII. 6-9. link: https://www.hte.hu/documents/3102649/4239802/ HT_2017_1_2_Horvath.pdf Downloaded: 21 January 2019.

P. Baranyi - A. Csapo - G. Sallai (2015): Cognitive Infocommunications (CoglnfoCom). Springer International Publishing.

B. Lampert - A. Pongracz - J. Sipos - A. Vehrer \& I. Horvath (2018): MaxWhere VR-Lear- 
ning Improves Effectiveness over Clasiccal Tools of e-learning. Acta Polytechnica Hungarica, 15(3).

Horvath Ildikó (2019): MaxWhere 3D Capabilities Contributing to the Enhanced Efficiency of the Trello 2D Management Software. Acta Polytechnica Hungarica, vol 16, no 6, pp. 55-71. Horvath I. - Sudar A. (2018): Factors contributing to the enhanced performance of the Maxwhere 3d VR platform in the distribution of digital information. Acta Polytechnica Hungarica, vol 15, no 3, pp. 149-173.

E. Gogh - A. Kovari (2019): Experiences of Self-regulated Learning in a Vocational Secondary School. Journal of Applied Technical and Educational Sciences, Vol 9, No 2, 72-86. 